\title{
Clinical Significance of the Echogenicity in Prostatic Ultrasound Findings in the Detection of Prostatic Carcinoma
}

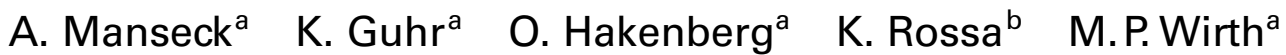 \\ ${ }^{a}$ Klinik und Poliklinik für Urologie, \\ ${ }^{\mathrm{b}}$ Institut und Poliklinik für Arbeits- und Sozialmedizin, Universitätsklinikum Carl Gustav Carus, Technische Universität Dresden
}

\section{Key Words}

Prostatic carcinoma $\cdot$ Biopsy of the prostate $\cdot$ Transrectal ultrasound $\cdot$ Echogenicity

\begin{abstract}
Summary
Background:Transrectal ultrasound is commonly performed in the clinical evaluation of the prostate. Ultrasound-guided randomized sextant biopsy became the standard procedure for the diagnosis of carcinoma of the prostate (CaP). A guided biopsy of sonographically irregular lesions of the prostate is not performed in randomized biopsies. An almost generally accepted opinion is that hypoechoic lesions are suspicious for the presence of CaP. However, the role of prostatic lesions with an echogenicity other than iso- or hypoechoic, e. g. hyperechoic or irregular lesions in relation to $\mathrm{CaP}$ is not clear. The intention of the present prospective study was to clarify the role of different prostatic ultrasound findings with a new-generation ultrasound probe in regard to their relevance concerning the presence of cancer. Material and Methods: 265 patients who were referred for prostatic evaluation because of an elevated PSA serum level or a positive digital rectal examination were enrolled in a prospective study. All patients had a systematic ultrasound-guided sextant biopsy of the prostate and a 4-core biopsy of the transition zone. All biopsy cores taken were guided by transrectal ultrasound. In case of a sonographically suspicious lesion, biopsy was always directed into this area. The predominant ultrasound appearance was separately recorded for each core. Results: Carcinoma of the prostate was detected in 87 $(32.8 \%)$ of the 265 patients. Biopsy cores with isoechoic ultrasound findings revealed $\mathrm{CaP}$ in $7.6 \%$. The data for hypoechoic, hyperechoic, mixed-echoic and anechoic lesions were 34.5, 26.9, 21.1 and $0 \%$, respectively. Hypoechoic ultrasound findings were less frequently found in the transition zone of the prostate, but the rate of $\mathrm{CaP}$ detection was the same as in the peripheral zone of the prostate. Conclusions: The transrectal ultrasound pattern of the prostate yields important information about the presence of carcinoma of the prostate. Especially hypoechoic lesions indicate the presence of $\mathrm{CaP}$ in a significant proportion of cases. However, hyperechoic lesions and lesions of mixed or irregular echogenicity were found to contain cancer in significant numbers as well, and should therefore be considered to be suspicious for cancer when performing transrectal ultrasound of the prostate. Directed biopsy of irregular ultrasound patterns in the prostate seems therefore to be recommendable.
\end{abstract}

\section{Schlüsselwörter}

Prostatakarzinom · Prostatabiopsie · Transrektaler Ultraschall . Echogenität

\section{Zusammenfassung}

Hintergrund: Der transrektale Ultraschall ist die häufigste bildgebende Untersuchung zur klinischen Beurteilung der Prostata. Zur Diagnostik des Prostatakarzinoms (PCa) hat sich die ultraschallgesteuerte Sextanten-Biopsie als Standardverfahren etabliert. Eine gezielte Biopsie irregulärer Ultraschallbezirke ist hier nicht vorgesehen. Es ist jedoch bekannt, daß sonographisch echoarm erscheinende Areale suspekt für die Präsenz eines PCa sind. Die Wertigkeit nicht einheitlicher oder echoreicher Ultraschallmuster ist jedoch bisher nicht zweifelsfrei geklärt. Ziel der vorliegenden Arbeit war es, mit einem Ultraschallgerät der neuesten Generation die Bedeutung der verschiedenen Ultraschallmuster bezüglich des Vorhandenseins von Prostatakarzinomen zu klären. Material und Methoden: 265 Patienten mit erhöhten PSA-Serumwerten oder suspekten Tastbefunden der Prostata wurden in die prospektive Untersuchung eingeschlossen. Bei allen Patienten wurden systematische, ultraschallgesteuerte Prostatabiopsien, wie in der Sextantenbiopsie vorgesehen, und 4 Zylinder aus der Transitionalzone entnommen. Bei der Biopsie wurde jedoch gezielt die Punktion in Bereichen von - falls vorhanden - irregulärem Ultraschallmuster vorgenommen und das entsprechende Ultraschallbild dokumentiert. Ergebnisse: Bei 87 der 265 Patienten $(32,8 \%)$ wurden Prostatakarzinome nachgewiesen. Biopsiezylinder aus isodensen Bereichen wiesen in 7,6\% ein Prostatakarzinom auf. Die Karzinomhäufigkeit bei Biopsie von echoarmen und echoreichen Arealen sowie von Arealen mit unterschiedlichen Echomustern und von zystischen Arealen wurde mit 34,5, 26,9, 21,1 bzw. 0\% ermittelt. Echoarme Befunde wurden seltener in der Transitionalzone nachgewiesen, waren jedoch dort in etwa gleicher Häufigkeit mit einem Karzinom verbunden wie in der peripheren Zone. Schlußfolgerungen: Das transrektale Ultraschallmuster in der Prostata liefert wichtige Hinweise auf das Vorhandensein eines Prostatakarzinoms. Insbesondere echoarme Läsionen deuten auf ein PCa hin. Echoreiche Läsionen und solche mit unterschiedlichen Echomustern enthielten jedoch Karzinome in so bedeutender Anzahl, daß diese Läsionen ebenfalls als karzinomverdächtig eingestuft werden müssen und auch eine gezielte Biopsie dieser Areale im Rahmen der Sextantenbiopsie empfehlenswert erscheint.

\section{KARGER \\ (C) 2000 S. Karger GmbH, Freiburs \\ Fax +497614520714 \\ E-mail Information@Karger.de \\ www.karger.com}

Dr. med. Andreas Manseck

Klinik und Poliklinik für Urologie, Universitätsklinikum Carl Gustav Carus Technische Universität Dresden

Fetscherstraße 74, D-01307 Dresden (Germany)

Tel. +49 351 458-2162, Fax -4333 


\section{Introduction}

In the early 1980 s, cancer of the prostate $(\mathrm{CaP})$ was believed to have a hyperechoic appearance in transrectal ultrasound (TRUS) [1-3]. In 1985, Lee and co-workers [4], however, demonstrated that $\mathrm{CaP}$ in the peripheral zone has a predominantly hypoechoic ultrasound pattern. These findings were confirmed by other investigators [5,6]. In the meantime, further technical (ultrasound consoles) and diagnostic improvements (TRUS-guided biopsy, systematic sextant biopsy, transition zone biopsy) were made. Especially PSA-based screening programs led to an increase in the number of $\mathrm{CaPs}$ detected and to an increase of patients subjected to biopsy. This resulted in a stage shift from more advanced $\mathrm{CaP}$ towards $\mathrm{T} 2$ and nonpalpable T1c CaP. However, there is a large number of patients with benign histologies on systematic sextant biopsies of the peripheral zone (65.6-82.1\%) [7, 8]. In such cases, further biopsies may reveal the presence of $\mathrm{CaP}$ in up to $21 \%$ according to Keetch et al. [9]. A more differentiated use of biopsy techniques with ultrasound diagnostic could be helpful in reducing the number of unnecessary (primary and further) prostatic biopsies and would increase the number of CaPs detected. Therefore, in the present prospective study all isoechoic and suspicious lesions in peripheral and transition zone TRUS were analyzed in relation to the rate of $\mathrm{CaPs}$ detected.

\section{Materials and Methods}

Between September 1997 and July 1999, 265 men referred for systematic prostate biopsy were included in this prospective study. Indications for prostate biopsy were an elevation of the PSA value in serum (PSA $\geq 4 \mathrm{ng}$ / $\mathrm{ml} ; \mathrm{n}=238$ ) and/or a digital rectal examination (DRE) suspicious for $\mathrm{CaP}$ $(n=99)$. Serum PSA levels were determined before any rectal manipulations with the Abbott AxSym enzyme immunoassay (Abbott, Wiesbaden, Germany). DRE was performed, and the findings were classified as benign, benignly enlarged or suspect. Urinary examination was carried out in all patients. Patients with urinary tract infections were treated by antibiotics corresponding to urinary culture and sensitivity testing. The prostate biopsy was postponed in all cases of urinary tract infections. In all other patients, ciprofloxacin $(2 \times 250 \mathrm{mg}$ b.d.) was administered for 5 days as a prophylactic antibiotic treatment, beginning 2 days before the biopsy. Careful counseling relative to the possible complications was carried out, and both verbal and written consent was obtained. All men underwent real-time transrectal ultrasound using a Siemens Versa (7.5-MHz biplanar) ultrasound probe (Siemens, Erlangen, Germany). Each prostate was examined in sagittal and axial projections. The distinction between peripheral and transition zones was recognizable in all cases. Core biopsies were obtained using an automatic biopsy device (Urotech, Bruckmühl, Germany). From each lobe 5 cores were taken: 3 cores from the peripheral zone (apex, midgland and base of the prostate) according to the systematic sextant biopsy technique described previously by Hodge et al. [10], and 2 from the transition zone. If there was a suspicious ultrasound finding, the biopsy needle was directed into this area. For each core taken, the predominant ultrasound pattern was recorded and classified as isoechoic, hypoechoic, hyperechoic or anechoic. Areas of non-uniform ultrasound patterns were classified as mixed-echoic. Biopsy specimens were processed separately and evaluated for the presence of $\mathrm{CaP}$. All tumors were classified according to the TNM classification of 1997 [11].

Statistical analysis was carried out with 'SPSS for Windows' 8.0. Distribution of variance was tested with the chi-square test. A univariate ANOVA was done, and differences in means were analyzed with the Scheffé and Tamhane procedure. The level of significance was set at $5 \%$ probability of error.

\section{Results}

The mean PSA serum level of all patients was 40.89 (median 8.3) $\mathrm{ng} / \mathrm{ml}$, with a range of 0.4 to $3,773 \mathrm{ng} / \mathrm{ml}$. Histological examination was done in all cases and revealed the presence of $\mathrm{CaP}$ in 87 of 265 patients (32.8\%). Tumor stages were classified as T1c $(n=19)$, T2 $(n=43)$, T3 $(n=18)$, and T4 $(n=7)$. According to the TNM classification of 1997, 20 of the 43 T2 tumors had a negative rectal finding but TRUS was suspicious for $\mathrm{CaP}$, and 23 patients had a positive DRE. In the 87 patients with $\mathrm{CaP}, 4.02$ core biopsies were positive on average (range 1-10). In 27 patients $(31 \%), \mathrm{CaP}$ was present in the peripheral zone only. In 5 patients $(5.8 \%), \mathrm{CaP}$ was histologically confirmed in the transition zone only, and 55 cancers $(63.2 \%)$ were found in both peripheral and transition zones.

The results of the ultrasonographic examination and the corresponding histological findings for each biopsy core are presented in table 1. Biopsies taken from tissue with isoechoic pattern revealed $\mathrm{CaP}$ in $7.6 \%$ of cases only, whereas a hypoechoic lesion was associated with $\mathrm{CaP}$ in $34.5 \%$ of all biopsy cores. In addition, biopsy cores taken from regions with hyperechoic or mixed-echoic appearance were also connected with the presence of $\mathrm{CaP}$ in a significant proportion (26.9 and $21.1 \%$, respectively). In contrast, biopsies taken from cystic lesions never revealed $\mathrm{CaP}$ (table 1).

Regarding statistical analysis, a significant correlation between histological result (benign histology, prostatic intraepithelial neoplasia (PIN), CaP) and ultrasound appearance of the prostatic tissue biopsied was found (chi-square test $\mathrm{p}=0.000$, $\mathrm{X}^{2}=245.72$; contingency coefficient $=0.291$ ).

Univariate analysis of variance showed also a significant difference in mean group values for histology and for the number of different ultrasound findings (isoechoic, hypoechoic, hyperechoic, mixed-echoic, anechoic).

The Scheffé and Tamhane procedure showed also a significant difference for mean values for histologically benign and $\mathrm{CaP}$ results $(\mathrm{p}=0.000)$, but not for PIN findings $(\mathrm{p}=0.849)$.

In tables 2 and 3 the results for the patients with positive or negative DRE are demonstrated. A significant correlation between histological results and ultrasound patterns was found in patients with suspicious DRE (chi-square test $\mathrm{p}=0.000$, $\mathrm{X}^{2}=259.51$; contingency coefficient $=0.308$ ). Univariate analysis of variance showed a significant difference in mean group values for the benign histology, $\mathrm{PIN}$ and $\mathrm{CaP}$ for the number of different ultrasound findings $(\mathrm{p}=0.000)$ (table 2). The Scheffé and Tamhane procedure gave a statistically significant difference for mean values for histologically benign and $\mathrm{CaP}$ results $(\mathrm{p}=0.000)$, but not for PIN findings $(\mathrm{p}=0.703)$ (table 2$)$. The chi-square test could not be applied for patients with negative DRE (table 3), as there were more than $20 \%$ of predicted values below $5\left(\mathrm{X}^{2}=37.81\right.$; contingency coefficient $=0.149$ for patients with negative rectal findings). In addition, the univariate analysis of variance did not show a significant difference in mean group values $(\mathrm{p}=0.824)($ table 3$)$.

The results of the 130 patients (49.1\%) with hypoechoic lesions in the transrectal ultrasound examination are presented in table 4 . These were detected in the peripheral zone in 70 cases, in the transition zone in 23 cases, and in both peripheral and transition zones in 37 cases. In 54 of the 130 patients with 
Table 1. Results of each core biopsy of the prostate in relation to the sonographically determined appearance of the area biopsied in correlation to statistical analysis (chi-square test)

Table 2. Results of each core biopsy of the prostate of patients with positive findings in DRE in relation to the sonographically determined appearance of the area biopsied in correlation to statistical analysis (chi-square test)

\begin{tabular}{|c|c|c|c|c|c|c|}
\hline \multirow{2}{*}{$\begin{array}{l}\text { Histological } \\
\text { result }\end{array}$} & \multicolumn{6}{|c|}{ Ultrasonographical tissue appearance (all patients) } \\
\hline & isodense & hypoechoic & hyperechoic & mixed-echoic & anechoic & total \\
\hline \multicolumn{7}{|l|}{ Benign } \\
\hline \multicolumn{7}{|l|}{ Biopsy cores } \\
\hline Number & 1,559 & 188 & 168 & 166 & 127 & 2,208 \\
\hline Expected*, n & $1,460.6$ & 255.8 & 195.0 & 185.8 & 110.8 & $2,208.0$ \\
\hline Histology, \% & 70.6 & 8.5 & 7.6 & 7.5 & 5.8 & 100.0 \\
\hline Ultrasound, \% & 88.9 & 61.2 & 71.8 & 74.4 & 95.5 & 83.3 \\
\hline \multicolumn{7}{|l|}{$P I N$} \\
\hline \multicolumn{7}{|l|}{ Biopsy cores } \\
\hline Number & 60 & 13 & 3 & 10 & 6 & 92 \\
\hline Expected*, n & 60.9 & 10.7 & 8.1 & 7.7 & 4.6 & 92.0 \\
\hline Histology, \% & 65.2 & 14.1 & 3.3 & 10.9 & 6.5 & 100.0 \\
\hline Ultrasound, \% & 3.4 & 4.2 & 1.3 & 4.5 & 4.5 & 3.5 \\
\hline \multicolumn{7}{|l|}{$\mathrm{CaP}$} \\
\hline \multicolumn{7}{|l|}{ Biopsy cores } \\
\hline Number & 134 & 106 & 63 & 47 & 0 & 350 \\
\hline Expected*, n & 231.5 & 40.5 & 30.9 & 29.5 & 17.6 & 350.0 \\
\hline Histology, \% & 38.3 & 30.3 & 18.0 & 13.4 & 0.0 & 100.0 \\
\hline Ultrasound, \% & 7.6 & 34.5 & 26.9 & 21.1 & 0.0 & 13.2 \\
\hline \multicolumn{7}{|l|}{ Total } \\
\hline \multicolumn{7}{|l|}{ Biopsy cores } \\
\hline Number & 1,753 & 307 & 234 & 223 & 133 & 2,650 \\
\hline Expected*,n & $1,753.0$ & 307.0 & 234.0 & 223.0 & 133.0 & $2,650.0$ \\
\hline Histology, \% & 66.2 & 11.6 & 8.8 & 8.4 & 5.0 & 100.0 \\
\hline Ultrasound, \% & 100.0 & 100.0 & 100.0 & 100.0 & 100.0 & 100.0 \\
\hline
\end{tabular}

*Expected by chi-square test.

\begin{tabular}{|c|c|c|c|c|c|c|}
\hline \multirow{2}{*}{$\begin{array}{l}\text { Histological } \\
\text { result }\end{array}$} & \multicolumn{6}{|c|}{ Ultrasonographical tissue appearance in patients with positive DRE $(\mathrm{n}=99)$} \\
\hline & isodense & hypoechoic & hyperechoic & mixed-echoic & anechoic & total \\
\hline \multicolumn{7}{|l|}{ Benign } \\
\hline \multicolumn{7}{|l|}{ Biopsy cores } \\
\hline Number & 422 & 90 & 96 & 61 & 29 & 698 \\
\hline Expected*, n & 365.9 & 128.3 & 110.0 & 72.6 & 21.2 & 698.0 \\
\hline Histology, \% & 60.5 & 12.9 & 13.8 & 8.7 & 4.2 & 100.0 \\
\hline Ultrasound, \% & 81.3 & 49.5 & 61.5 & 59.2 & 96.7 & 70.5 \\
\hline \multicolumn{7}{|l|}{ PIN } \\
\hline \multicolumn{7}{|l|}{ Biopsy cores } \\
\hline Number & 12 & 2 & 2 & 5 & 1 & 22 \\
\hline Expected*, n & 11.5 & 4.0 & 3.5 & 2.3 & 0.7 & 22.0 \\
\hline Histology, \% & 54.5 & 9.1 & 9.1 & 22.7 & 4.5 & 100.0 \\
\hline Ultrasound, \% & 2.3 & 1.1 & 1.3 & 4.9 & 3.3 & 2.2 \\
\hline \multicolumn{7}{|l|}{$\mathrm{CaP}$} \\
\hline \multicolumn{7}{|l|}{ Biopsy cores } \\
\hline Number & 85 & 90 & 58 & 37 & 0 & 270 \\
\hline Expected*, n & 141.5 & 49.6 & 42.5 & 28.1 & 8.2 & 270.0 \\
\hline Histology, \% & 31.5 & 33.3 & 21.5 & 13.7 & 0.0 & 100.0 \\
\hline Ultrasound, \% & 16.4 & 49.5 & 37.2 & 35.9 & 0.0 & 27.3 \\
\hline \multicolumn{7}{|l|}{ Total } \\
\hline \multicolumn{7}{|l|}{ Biopsy cores } \\
\hline Number & 519 & 182 & 156 & 103 & 30 & 990 \\
\hline Expected*, n & 519.0 & 182.0 & 156.0 & 103.0 & 30.0 & 990.0 \\
\hline Histology, \% & 52.4 & 18.4 & 15.8 & 10.4 & 3.0 & 100.0 \\
\hline Ultrasound, \% & 100.0 & 100.0 & 100.0 & 100.0 & 100.0 & 100.0 \\
\hline
\end{tabular}


Table 3. Results of each core biopsy of the prostate of patients with negative findings in digital rectal examination in relation to the sonographically determined appearance of the area biopsied in correlation to statistical analysis (chi-square test)

\begin{tabular}{|c|c|c|c|c|c|c|}
\hline \multirow{2}{*}{$\begin{array}{l}\text { Histological } \\
\text { result }\end{array}$} & \multicolumn{6}{|c|}{ Ultrasonographical tissue appearance in patients with negative DRE $(n=166)$} \\
\hline & isodense & hypoechoic & hyperechoic & mixed-echoic & anechoic & total \\
\hline \multicolumn{7}{|l|}{ Benign } \\
\hline \multicolumn{7}{|l|}{ Biopsy cores } \\
\hline Number & 1,137 & 98 & 72 & 105 & 98 & 1,510 \\
\hline Expected*, n & $1,122.5$ & 113.7 & 71.0 & 109.2 & 93.7 & $1,510.0$ \\
\hline Histology, \% & 75.3 & 6.5 & 4.8 & 7.0 & 6.5 & 100.0 \\
\hline Ultrasound, \% & 92.1 & 78.4 & 92.3 & 87.5 & 95.1 & 91.0 \\
\hline \multicolumn{7}{|l|}{ PIN } \\
\hline \multicolumn{7}{|l|}{ Biopsy cores } \\
\hline Number & 48 & 11 & 1 & 5 & 5 & 70 \\
\hline Expected*, n & 52.0 & 5.4 & 3.3 & 5.1 & 4.3 & 70.0 \\
\hline Histology, \% & 68.6 & 15.7 & 1.4 & 7.1 & 7.1 & 100.0 \\
\hline Ultrasound, \% & 3.9 & 8.8 & 1.3 & 4.2 & 4.9 & 4.2 \\
\hline \multicolumn{7}{|l|}{$\mathrm{CaP}$} \\
\hline \multicolumn{7}{|l|}{ Biopsy cores } \\
\hline Number & 49 & 16 & 5 & 10 & 0 & 80 \\
\hline Expected*, n & 59.5 & 6.0 & 3.8 & 5.8 & 5.0 & 80.0 \\
\hline Histology, \% & 61.3 & 20.0 & 6.3 & 12.5 & 0.0 & 100.0 \\
\hline Ultrasound, \% & 4.0 & 12.8 & 6.4 & 8.3 & 0.0 & 4.8 \\
\hline \multicolumn{7}{|l|}{ Total } \\
\hline \multicolumn{7}{|l|}{ Biopsy cores } \\
\hline Number & 1,234 & 125 & 78 & 120 & 103 & 1,660 \\
\hline Expected*, n & $1,234.0$ & 125.0 & 78.0 & 120.0 & 103.0 & $1,660.0$ \\
\hline Histology, \% & 74.3 & 7.5 & 4.7 & 7.2 & 6.2 & 100.0 \\
\hline Ultrasound, \% & 100.0 & 100.0 & 100.0 & 100.0 & 100.0 & 100.0 \\
\hline
\end{tabular}

*Expected by chi-square test. hypoechoic lesions, a $\mathrm{CaP}$ was detected. In 45 of these 54 patients, $\mathrm{CaP}$ was histologically confirmed in hypoechoic lesions, and in 9 of the 54 patients the localization of the $\mathrm{CaP}$ was other than in the hypoechoic lesion. The presence of a hypoechoic lesion in the peripheral or transition zone only was associated with a $\mathrm{CaP}$ in a corresponding biopsy core in $29.7 \%$ and $20 \%$, respectively. If hypoechoic lesions were present in both peripheral and transition zones, a $\mathrm{CaP}$ was detected in $59.5 \%$. The mean number of biopsy cores with a hypoechoic ultrasound pattern was $0.84 \pm 1.3$ in patients with a benign histology vs $1.8 \pm 1.98$ in patients with $\mathrm{CaP}$. In all patients with $\mathrm{CaP}$, an average of 4.2 biopsy cores was taken from suspicious lesions (hypoechoic, hyperechoic or mixed-echoic) (fig. 1). In patients with benign histology, only 2.2 biopsy cores showed sonographically suspicious lesions.

\section{Discussion}

Randomized sextant biopsy of the prostate as described by Hodge et al. [10] in 1989 was established as the standard diagnostic procedure in the evaluation of patients with the suspicion of $\mathrm{CaP}$. However, as many as $41.5 \%$ of significant CaPs may be missed by one set of prostatic biopsies, as could be demonstrated by Djavan et al. [12] who performed two consecutive sets of prostatic biopsies in a group of 1,051 patients (PSA serum levels 4-10 ng/ml). Efforts have therefore
Table 4. Results of histological examination in patients with biopsy cores taken from areas that appear sonographically hypoechoic; distribution to peripheral (PZ) and transition zone (TZ)

\begin{tabular}{lll}
\hline $\begin{array}{l}\text { Hypoechoic pattern } \\
\text { in sonography }\end{array}$ & $\mathrm{CaP}$ & $\begin{array}{l}\text { Benign } \\
\text { histology }\end{array}$ \\
\hline Only TZ, n & $4\left(+3^{*}\right)$ & 16 \\
Only PZ, n & $19\left(+6^{*}\right)$ & 45 \\
TZ + PZ, n & 22 & 15 \\
Total, n & 54 & 76 \\
\hline
\end{tabular}

*3 and 6 patients, respectively, had a hypoechoic ultrasound pattern and $\mathrm{CaP}$, but the tumor was detected in other regions of the prostate.

been made to improve the detection rate of the systematic sextant biopsy of the prostate and to reduce the number of secondary prostatic biopsies. Under investigation is the modification of the number and site of core biopsies taken [13,14], and mathematical models for the correct number of core biopsies per patient were established [15].

In this prospective study, extended systematic sextant biopsies of the prostate - extended with 4 additional biopsies of the transition zone - were done on patients with a suspicion of $\mathrm{CaP}$. In the study performed herein, biopsy was ultrasoundguided, and if irregular ultrasound findings were present, 

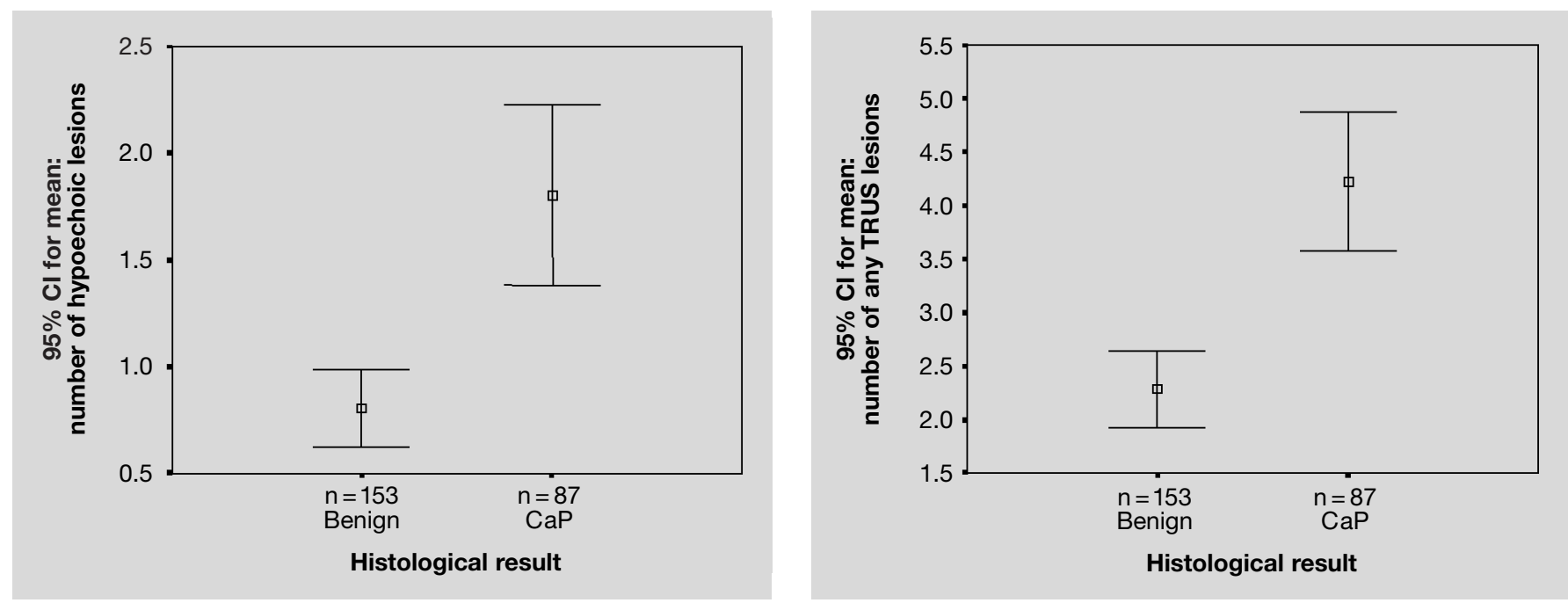

Fig. 1. Error bar charts for mean values of hypoechoic (a) and all suspect ultrasound findings (b) per patient and different histological results with $95 \%$ confidence intervals. $\mathbf{a}$ and $\mathbf{b} \mathrm{p}=0.000$ for differences between groups.

biopsy cores were directly taken from the suspicious lesion. This is in contrast to the standard sextant biopsy technique, where ultrasound is only used to receive randomized biopsy cores. For each biopsy core, the predominant ultrasound pattern was documented and analyzed in relation to the histological result of the corresponding biopsy core. The intention of the present study was to evaluate the importance of prostatic ultrasound findings other than isoechoic.

It is generally accepted that prostatic biopsy is indicated in patients with a PSA elevation $>4 \mathrm{ng} / \mathrm{ml}$ or with palpable abnormalities of the prostate. In addition, it is accepted that hypoechoic areas that can be recognized on transrectal ultrasound examination of the prostate are often associated with the presence of $\mathrm{CaP}$. The mere presence of any hypoechoic lesions in the peripheral zone is stated to be associated with a sensitivity of $86 \%$ and a specificity of $45 \%$ for the detection of $\mathrm{CaP}$ [5]. Considering TRUS as suspicious when a hypoechoic lesion was present anywhere in the prostate, the sensitivity of hypoechoic lesions for the presence of $\mathrm{CaP}$ was $62.1 \%$ and the specificity was $57.3 \%$ in the present study. Analysis for each core biopsy with isoechoic ultrasound pattern revealed $\mathrm{CaP}$ in $7.6 \%$ of biopsy cores only, whereas an echogenicity other than isoechoic was associated with a much higher rate of $\mathrm{CaP}$ detected (table 1). Cancer diagnosis was increased most when biopsying hypoechoic lesions with a detection rate of $34.5 \%$. But also taking biopsies from regions of hyperechoic or mixedechoic ultrasound appearance resulted in the detection of $\mathrm{CaP}$ in 26.9 and $21.1 \%$, respectively.

TRUS findings were examined in relation to DRE results by Devonec et al. [16]. In that study, 64 patients had a palpable nodularity on DRE, and CaP was found in 34 patients (53\%). All 64 patients in the study of Devonec et al. had an abnormal hypoechoic lesion on the transrectal scan. In our series, 99 patients had s suspicious finding on DRE and 52 (59.7\%) had CaP. 61 patients $(61.6 \%)$ of the 99 patients with positive DRE had hypoechoic lesions. In this subgroup, $\mathrm{CaP}$ was detected in
36 patients $(59.0 \%)$. Devonec et al. had 162 (27\%) of 602 patients with a negative DRE and a hypoechoic lesion on the TRUS exam, and all of them were biopsied. Histological examination revealed $\mathrm{CaP}$ in 11 of these patients $(6.7 \%)$. Thus, the rate of hypoechoic lesions representing $\mathrm{CaP}$ (45 of 226 patients) found in the study of Devonec et al. was lower than the rate in our study (45 of 130 patients) (19.9 and 34.6\%, respectively).

Norberg et al. [17] examined 512 men with the suspicion of $\mathrm{CaP}$ and found suspicious (hypo-, hyperechoic and irregular) ultrasound lesions in $328(64.1 \%)$ patients regardless of the DRE findings. $\mathrm{CaP}$ was detected in 276 patients $(53.9 \%)$. In that series, $\mathrm{CaP}$ corresponding to the TRUS findings was present in $57 \% .11 \%$ of the men in the study of Norberg et al. with hypo-/hyperechoic/irregular lesions had their cancer elsewhere in the gland. In another study by Cooner et al. [6], hypoechoic lesions were seen in the prostate less frequently [835 out of $1,807$ patients $(46.2 \%)]$. In all 835 cases guided biopsies of the suspicious lesions were performed, and $\mathrm{CaP}$ was found in 263 patients $(31.5 \%) ; 260$ of these lesions were identified in the peripheral or central zones, whereas only 3 cases $(1.1 \%)$ of $\mathrm{CaP}$ could be detected in the transition zone. This is in contrast to our study, in which $22.6 \%$ of the 265 patients had hypoechoic lesions in the transition zone, who were classified to be suspicious for $\mathrm{CaP}$. In $48.3 \%$ of these patients, biopsy proved positive for CaP. Supported by the data of McNeal et al. [18] who showed that $\mathrm{CaP}$ develops in the transition zone in about $24 \%$ of all prostatic carcinomas, the number of CaPs detected in the transition zone seems to be rather low and perhaps may be ascribed to the transition zone biopsy technique used by Cooner and co-workers [6].

In most studies, however, randomized transition zone biopsies were performed and suspicious areas were not directly biopsied as the transition zone is somewhat more hypoechoic in comparison to the peripheral zone. In the present study, pronounced hypoechoic ultrasound patterns were found less 
frequently in the transition zone than in the peripheral zone, but hypoechoic lesions were associated with $\mathrm{CaP}$ in the transition zone in $20 \%$ and in the peripheral zone in $29.7 \%$. Under the condition that hypoechoic lesions were present in both peripheral and transition zones, $\mathrm{CaP}$ was detected in $59.5 \%$. In our opinion, pronounced hypoechoic lesions in the transition zone therefore have to be taken into account when suspecting $\mathrm{CaP}$.

The present study also shows a high number of $\mathrm{CaP}$ in hyperechoic and echo-mixed/irregular lesions. Although there are some studies in which hyperechoic areas have been found to be associated with $\mathrm{CaP}$, exact data with new ultrasound technique are not available. The majority of examiners assess only hypoechoic areas as suspicious for CaP. Most prostate biopsy studies do not directly relate to the echogenicity of the prostatic tissue, and it is not always clear whether all suspicious prostatic lesions or hypoechoic lesions only were biopsied. In the present study all suspicious lesions, i.e. areas appearing not isoechoic, were biopsied, and in all patients 10 core biopsies, representative of the peripheral and the transition zone, were taken. As a result, the number of lesions per prostate classified as of hypo-, hyper- or mixed-echoic appearance could be identified as predictive for $\mathrm{CaP}$. Thus, when taking into account all suspicious ultrasound patterns and the number found in each patient, this could be helpful in avoiding repeated unnecessary prostatic biopsies.

In conclusion, echogenicity in prostatic ultrasound is highly informative, and guided biopsies may increase the rate of $\mathrm{CaP}$ detected. Although hypoechoic lesions in transrectal ultrasound are most often associated with the presence of $\mathrm{CaP}$, hyperechoic lesions and lesions with a mixed/irregular ultrasound appearance contain the 3- to 4-fold number of $\mathrm{CaP}$ in comparison to isoechoic (normal) prostatic tissue. In addition, transition zone ultrasound shows hypoechoic lesions less frequently, but when seen, transition zone hypoechogenicity is associated with $\mathrm{CaP}$ in nearly the same frequency as in the peripheral zone. From our data, directed biopsies of irregular ultrasound findings with a modern ultrasound equipment seem to be advisable to increase the detection rate of $\mathrm{CaP}$.

\section{References}

1 Resnick MI, Willard JW, Boyce WH: Transrectal ultrasonography in the evaluation of patients with prostatic carcinoma. J Urol 1980;124:482-484.

2 Watanabe H, Date S, Ohe H, Saitoh M, Tanaka S: A survey of 3,000 examinations by transrectal ultrasonography. Prostate 1980;1:271-278.

3 Brooman PJC, Griffiths GJ, Roberts E, Peeling WB,

Evans K: Per rectal ultrasound in the investigation of prostatic disease. Clin Radiol 1981;32:669-676.

4 Lee F, Gray JM, McLeary RD, Meadows TR, Kumasaka GH, Borlaza GS, Straub WH, Lee F, Solomon MH, McHugh TA, Wolf RM: Transrectal ultrasound in the diagnosis of prostate cancer: Location, echogenicity, histopathology, and staging. Prostate 1985; 7:117-129.

5 Hammerer P, Huland H: Zur Diagnostik des lokalisierten Prostatakarzinoms: Screening und präoperatives Staging. Urologe A 1991;30:378-386.

6 Cooner WH, Mosley BR, Rutherford CL, Beard JH Pond HS, Terry WM, Igel TC, Kidd DD: Prostate cancer detection in a clinical urological practice by ultrasonography, digital rectal examination and prostate specific antigen. J Urol 1990;143:1146-1154.
7 Catalona WJ, Smith DS, Ratliff TL, Basler JW: Detection of organ-confined prostate cancer is increased through prostate-specific antigen-based screening. JAMA 1993;270:948-954.

8 Rietbergen JBW, Boeken Kruger AE, Kranse R Schröder FH: Complications of transrectal ultrasound-guided systematic sextant biopsies of the prostate: Evaluation of complication rates and risk factors within a population-based screening program. Urology 1997;49:875-880.

9 Keetch DW, Catalona WJ, Smith DS: Serial prostatic biopsies in men with persistently elevated serum prostate specific antigen values. J Urol 1994;151 1571-1574.

10 Hodge KK, McNeal JE, Stamey TA: Ultrasound guided transrectal core biopsies of the palpably abnormal prostate. J Urol 1989;142:66-70.

11 Wittekind C, Wagner C: TNM-Klassifikation maligner Tumoren, Aufl. 5. Berlin, Springer, 1997.

12 Djavan B, Zlotta A, Bursa B, Marberger M: Evaluierung der Notwendigkeit einer Prostata-Re-Biopsie: Prospektive Analyse von 1051 Fällen. Urologe A 1999;38:S73.
13 Reissigl A, Pointner J, Strasser H, Ennemoser O, Klocker H, Bartsch G: Frequency and clinical significance of transition zone cancer in prostate cancer screening. Prostate 1997;30:130-135.

14 Eskew LA, Bare RL, McCullough: Systematic 5 region prostate biopsy is superior to sextant method for diagnosing carcinoma of the prostate. J Urol 1997;157:199-203.

15 Vashi AR, Wojno KJ, Gillespie B, Oesterling JE: A model for the number of cores per prostate biopsy based on patient age and prostate gland volume. J Urol 1998;159:920-924.

16 Devonec M, Chapelon JY, Cathignol D: Comparison of the diagnostic value of sonography and rectal examination in cancer of the prostate. Eur Urol 1988;14:189.

17 Norberg M, Egevad L, Holmberg L, Sparen P, Norlen BJ, Busch C: The sextant protocol for ultrasound-guided core biopsies of the prostate underestimates the presence of cancer. Urology 1997;50: 562-566.

18 McNeal JE, Redwine EA, Freiha FS, Stamey TA: Zonal distribution of prostatic adenocarcinoma. Am J Surg Pathol 1988;12:897-906. 